IZA DP No. 6622

Remittances and Portfolio Values:

An Inquiry Using Spanish Immigrants from Africa, Europe and the Americas

Catalina Amuedo-Dorantes

Susan Pozo

June 2012 


\title{
Remittances and Portfolio Values: An Inquiry Using Spanish Immigrants from Africa, Europe and the Americas
}

\author{
Catalina Amuedo-Dorantes \\ San Diego State University \\ and IZA \\ Susan Pozo \\ Western Michigan University
}

Discussion Paper No. 6622

June 2012

IZA

P.O. Box 7240

53072 Bonn

Germany

Phone: +49-228-3894-0

Fax: +49-228-3894-180

E-mail: iza@iza.org

Any opinions expressed here are those of the author(s) and not those of IZA. Research published in this series may include views on policy, but the institute itself takes no institutional policy positions.

The Institute for the Study of Labor (IZA) in Bonn is a local and virtual international research center and a place of communication between science, politics and business. IZA is an independent nonprofit organization supported by Deutsche Post Foundation. The center is associated with the University of Bonn and offers a stimulating research environment through its international network, workshops and conferences, data service, project support, research visits and doctoral program. IZA engages in (i) original and internationally competitive research in all fields of labor economics, (ii) development of policy concepts, and (iii) dissemination of research results and concepts to the interested public.

IZA Discussion Papers often represent preliminary work and are circulated to encourage discussion. Citation of such a paper should account for its provisional character. A revised version may be available directly from the author. 


\section{ABSTRACT \\ Remittances and Portfolio Values: An Inquiry Using Spanish Immigrants from Africa, Europe and the Americas}

Using a recent Spanish database, we show that remittances respond to cross country differences in portfolio values. This behavior suggests that immigrants are sophisticated economic optimizers who take advantage of opportunities to invest trans-nationally given the networks that immigrants are likely to have developed both in their host and home communities. The responsiveness to portfolio variables persists whether immigrants are highly or less highly educated. However, there are differences in the individual portfolio variables to which immigrants from various regions of the world respond to, as we would expect given migrants' diverse backgrounds and motives for emigrating. Additionally, remitting patterns change over time with the length of the migration spell, suggesting that remittances sent for portfolio motives become more likely as the immediate needs of family left back home are addressed and immigrants settle down in their host communities.

JEL Classification: F24, F22

Keywords: remittances, portfolio motives, Spain

Corresponding author:

Catalina Amuedo-Dorantes

Department of Economics

San Diego State University

5500 Campanile Drive

San Diego, CA 92182

USA

E-mail: camuedod@mail.sdsu.edu 


\section{Introduction}

In this paper, we show that immigrants' remittances are responsive to portfolio variables, rising and falling with risks and expected returns. In some respects, this behavior is at odds with the New Economics of Labor Migration (NELM) paradigm, which focuses on remittances as a byproduct of migration undertaken to diversify risk spatially. According to the NELM, by spreading out geographically, idiosyncratic income shocks to a family member in one community may be offset with income from family members residing in other communities not subject to the same shock (Rosenzweig and Stark, 1989). Remittances then flow across communities with the purpose of smoothing consumption.

While spatial diversification may function as a mechanism to insure and smooth consumption for families in migrant-sending countries in many circumstances, that may not be the case for emigrants themselves. This is particularly true in the case of migration from poorer to richer countries-- sometimes referred to as south to north migration. ${ }^{1}$ For instance, a son residing in Spain may be able to assist his Ecuadorian mother should she experience an economic downturn. However, it would likely be challenging for the mother to help her migrant son should he run into hard times. Because of the large differences in the cost of living between Ecuador and Spain, an alternative mechanism would be needed for the emigrant's consumption-smoothing.

We argue that asset accumulation is likely to serve that purpose. While migrants residing in rich countries may typically assist their family members living in poor countries, reciprocity in the other direction is less likely given the substantial income and cost of living differentials. In those

\footnotetext{
${ }^{1}$ South south migration refers to migration from a developing country to yet another developing country. In contrast, south north migration refers to migration from poor to rich countries. See Ratha and Shaw (2007) for the use of this terminology to distinguish between these two types of migration flows.
} 
instances, immigrants may need to set aside some of their earnings and engage in asset accumulation to insure against income shocks. ${ }^{2}$

The conclusion that individuals, whether they be natives or immigrants, engage in saving and asset accumulation for consumption smoothing purposes is not novel. ${ }^{34}$ However, what is peculiar about immigrants' saving behavior is that, unlike natives, immigrants have at their disposal transnational knowledge and transnational networks concerning their home and host communities. This knowledge and these networks can facilitate the accumulation of assets in two different locations -that is, in their home and host communities. As a result, immigrants, to a greater degree than the general public, have spatial alternatives with respect to asset holding. Asset holding preferences are likely to be guided, in part, by expected returns in each location. Consequently, when relative asset returns increase in the home country, more remittances are likely to be sent home for safekeeping. ${ }^{5}$ In contrast, migrants may choose to accumulate assets in the host country and remit less when relative asset returns rise in the host country. Our intent is to capture this behavior -that is, the responsiveness of remittances to portfolio variables.

At this juncture in the paper, it is important to note that we do not make the claim that all remittances are motivated by portfolio variables. It is well accepted that remittances are sent for many different reasons, such as contributing toward a family event (wedding, baptism, quinceañera celebration), to pay for children's school tuition, to pay back loans, and to help family and friends

\footnotetext{
${ }^{2}$ Reciprocity might still take place. For instance, the home family may care for the migrant's home assets or tend to her/his children in return for the availability of financial assistance from the migrant in times of need. Nonetheless, the emigrant still needs to save and accumulate assets as a means to insure her/himself against unforeseen income risks because the home family's resources may not be sufficient to sustain the migrant in the higher cost of living community.

${ }^{3}$ Throughout this paper, we use the terms asset accumulation, investment and saving interchangeably.

${ }^{4}$ Modigliani and Brumberg (1954) and Leland (1968) were the originators of the idea that households engaged in saving for consumtion smoothing purposes.

${ }^{5}$ See discussion by Taghavi (2012) of this behavior by migrant workers in Gulf Coast Community countries and Brown (1994) for migrants remitting to their home communities in the South Pacific.
} 
when in need of financial support. What we do stress, however, is that there are reasons to suspect that immigrants may wish to accumulate assets and that the distribution of those assets across home and host communities is likely to be influenced by portfolio variables. Hence, remittances are likely to be affected by relative returns to holding assets. This behavior is most likely to take place when it is more difficult for the home family to defray the immigrant's expenses in the host community, as is often the case in south to north migration. In these circumstances, the emigrant will need to insure her/himself against unforeseen risks by means other than tapping into the family’s resources back home.

While some studies have recognized that immigrants hold assets both at home and abroad (see, for example, Gammage 2007), few empirical investigations have sought to link relative macroeconomic conditions in the home and the host countries to individual migrants' remitting behavior. The relative absence of remittance studies specifically linking migrants' remitting patterns to portfolio values is likely due to lack of adequate data. Much of the more representative data on remittances originate from surveys that focus on migrants originating from a particular region. $^{6}$ For instance, there are various large surveys that detail remittance flows from Mexican migrants to their families in Mexico, such as the Mexican Migration Project (MMP) or the Encuesta de Migración de la Frontera Norte (EMIF). Nevertheless, most of the remittance flows in these two surveys originate in the same host country (i.e. the United States) and are sent to the same home country (i.e. Mexico) at a point in time. With no cross-country or cross-time variation

\footnotetext{
${ }^{6}$ There are a large number of small immigrant surveys carried out by a variety of research institutes and NGOs in the United States. Unfortunately, most of these surveys are small and are not designed with the intention of being representative of the migrant population in the host country. Indeed, they often focus on only one immigrant group. For example, the Florida International University Cuba Poll focuses on Cuban immigrants residing in South Florida, while the Inter-American Development Bank) Survey of Remittance to Mexico and Central America, focuses on senders from those two regions.
} 
in macroeconomic conditions, we cannot examine how variations in portfolio variables (reflecting changes in market conditions) impact individual's remittance flows.

In this study, we make use of a recent immigrant survey, the Encuesta Nacional de Inmigrantes (henceforth: ENI), released by the Spanish Statistical Institute (Instituto Nacional de Estadistica or INE). This Spanish immigration survey is ideal for the study at hand for various reasons. First, it was designed using the municipal population registers with the purpose of being as representative as possible of the immigrant stock in Spain at the time of the survey. Second, it informs on the remitting behavior of a geographically diverse group of immigrants. Indeed, the ENI benefits from the fact that Spain hosts immigrants from all Latin America, from numerous African nations, from a diverse number of European countries (members and non-members of the European Union) and from a handful of Asian nations. This diversity of origins allows us to examine migrants' remitting behavior in response to cross-country differences in macroeconomic conditions and other portfolio values. Finally, Spain offers an interesting case study owing to the unparalleled growth of its immigrant population during the past fifteen years and, in turn, of its remittance outflows, making Spain one of the leading countries from which remittance flows originate after the United States. ${ }^{7}$

Understanding whether and to what degree migrant remittances respond to cross-country differences in macroeconomic conditions -what we refer to as portfolio variables- is crucial for understanding the behavior of remittance flows. Specifically, can remittances be relied upon to shore up the home economy during an economic downturn? Or are remittances more likely to respond to economic and favorable portfolio variables? The current literature seems to primarily characterize remittances as a stabilizing force with many arguing that remittances serve as a reliable

\footnotetext{
${ }^{7}$ By 2006, Spain had the second highest immigration rates within the EU after Cyprus, and the second highest absolute net migration in the world after the United States (Lanzieri and Corsini 2006).
} 
source of foreign exchange for remittance receiving economies, in particular when their economies are in a slump. As such, countries with large emigrant populations are believed to be less susceptible to currency crises (Ratha 2004, Bugamelli and Paterno 2005). However, if remittances are responsive to portfolio variables, we need to question the assertion that remittances can always be counted on as a reliable source of foreign exchange to counteract speculative outflows and idiosyncratic negative shocks. Instead, we should prepare for the possibility that at the macroeconomic level remittances may be destabilizing. And perhaps, more importantly, we need to reconsider the behavior of immigrants remitting money home when portfolio values change as, quite often, immigrants are portrayed as unsophisticated investors who are either unaware or unresponsive to such values.

\section{Background on Immigration to Spain}

Before proceeding any further, it is important to provide an overview of immigration to Spain. Until quite recently, Spain was a country of emigrants (Ortega Pérez 2003). ${ }^{8}$ However, the arrival of democracy in 1975, the entry of Spain into the European Union (EU) in the 1980s, the long-standing decline in many African economies and the economic crises in several Latin American countries during the 1990s marked a sudden change. Within a decade, the foreign-born population quadrupled from 1.2 percent of the adult population (300,000 individuals) in 1991 to 4.0 percent (1,370,000 individuals) in 2001 (España en Cifras, 2008). ${ }^{9}$ Between 2001 and 2005, the foreign-born doubled to account for 8.0 percent of the population (3,100,000 individuals) and, by the time the ENI was implemented in 2007, immigrants represented 10 percent of the population

\footnotetext{
${ }^{8}$ In the period 1850-1950, 3.5 million Spaniards left for the Americas. Argentina received more than 1.5 million of these emigrants. Others went to Uruguay, Brazil, Cuba and also North Africa. Algeria received 94,000 Spanish emigrants in the last years of the 19th century. This flow shifted to Morocco (as well as Ceuta, Melilla and Tangier) after the establishment of the Spanish protectorate there in the period 1916-1919.

${ }^{9}$ Available at: http://www.ine.es/prodyser/pubweb/espcif/espcif.htm
} 
(i.e. 4.5 million immigrants out of 45.2 million inhabitants). The Spanish immigration rate became three to four times as large as the average immigration rate in the United States and, by 2009, Spain ranked seventh in annual remittance outflows measured in U.S. dollars (Ratha, Mohapara and Silwal, 2011).

In this study we focus on Spanish immigrants from Africa, the Americas and Europe -the main source regions. Indeed, approximately 34 percent of immigrants in our sample originate in the Americas, about 48 percent from EU members, 6.5 percent are non-EU Europeans and 11 percent are from Africa. Additionally, the most common countries-of-origin for immigrants in our sample (countries of origin for more than 5 percent of the entire pool of immigrants) are Morocco, Romania, Ecuador, Colombia, France, Argentina, and the United Kingdom. Further details on the immigrant sample are discussed in the data section.

\section{Remittances and Asset Accumulation}

There is a small literature examining the link between migrant remittances and the use of those outflows in asset accumulation or other expenditures in the home community. Some studies rely on migrants' self-reports regarding the purpose for which they remit money home (e.g. Roberts, 2009; Stahl and Arnold, 1996). In this vein, the Mexican Migration Project database reveals that about 11 percent of Mexicans who migrate to the United States and remit money home claim asset accumulation as the primary motive for remitting. ${ }^{10}$ While this information is interesting and does suggest that there are many motives for remitting, including an asset

\footnotetext{
${ }^{10}$ Authors' tabulations using the Mexican Migration Project data (MMP118) and lumping the following purposes into the "asset accumulation" category: construction or repair of a home, debt payment, saving, purchase of a home or lot, education expense, start/expand a business, purchase of agricultural inputs, purchase of livestock, purchase of a vehicle, purchase of tools.
} 
accumulation motive, we still lack information on the influence of portfolio variables on migrants' remitting behavior.

Another set of studies compares expenditure patterns of remittance-receiving households and non-receiving households. Using the Mexican National Rural Household Survey, Taylor and Mora (2006) conclude that households affected by international migration (and presumably receiving remittances) modify their expenditure patterns by increasing their share of expenditures on investment at the expense of consumption. Likewise, Adams (2005) finds that remittancereceiving households in Guatemala spend less on consumption (defined in his study as food, consumer goods and durables), and more on education, health and real estate relative to nonremittance receiving households. Similar findings are also reported by Zarate-Hoyos (2004) and Airola (2007). These studies, however, do not examine how differences in macroeconomic conditions impact migrants' remitting patterns as the data focus on households in the origin communities and not on the migrants sending money home.

A third set of studies focuses on testing whether there is an association between aggregate remittance inflows and various macroeconomic variables - including the exchange rate, exchange rate volatility, aggregate output, the inflation rate and interest rates. Faini (1994), Lianos (1997) and Higgins et al. (2004) all take this approach and estimate aggregate macroeconomic remittance functions. However, it is unclear what they can actually conclude. For example, while Faini (1994) and Higgins et al. (2004) find that home country real exchange rate depreciation increases remittance flows, the studies estimate aggregate remittance inflows. Aggregate remittance data do not allow us to clearly track how portfolio variables affect remittances because they do not inform where remittances originate from. For example, remittance inflows to Colombia originate not only from Spain, but also from the United States, Argentina, and many other countries where Colombian 
migrants settle. It is unclear then what the relationship between the average multilateral exchange rate (which could be made up of some currencies rising and others falling in relation to the Colombian peso) and aggregate inflows reveal about the response of individual level remittances to cross-country differences in portfolio variables.

The only study linking portfolio and macroeconomic conditions in the home and host countries to individual migrant remittances is a study by Pozo and Vargas-Silva (2006). The authors rely on individual level data from the Legalized Population Survey (LPS) -a survey carried out by the United States Department of Labor in 1987 and, again, in 1991 on a sample of undocumented migrants who adjusted their status following the passage of the Immigration Reform and Control Act (IRCA). They exploit the cross-country nature of this survey (with approximately 50 percent of the immigrants originating in Mexico and the other 50 percent originating in other countries around the globe) and find that individuals originating from countries that experience depreciation of the home currency tend to increase their remittances home. In contrast, individuals originating from countries that experience greater uncertainty in the home/host exchange rate tend to reduce their remittance outflows. While this paper is more closely related to the present study, it differs in a few regards. First, it works with a selected sample of migrants: newly legalized immigrants. As noted by Amuedo-Dorantes and Mazzolari (2010), there are reasons to believe that the remitting behavior of immigrants significantly changes post-legalization. Therefore, one has to be careful when making inferences about the asset accumulation or investment motives behind migrants' remitting patterns looking at such a selective sample of migrants. Additionally, the LPS survey was conducted approximately fifteen years ago. Given the transformed economic environment, one may question the applicability to today's world. 
In sum, there have been studies that examine the link between remittances and asset accumulation from a variety of perspectives -including studies that use information on the intentions of remitters, studies that examine the differential spending patterns of remittancereceiving and non-receiving households, studies that gauge how aggregate remittance inflows respond to changes in multilateral economic conditions, and one that analyzes how the remitting behavior of newly legalized immigrants responded to macroeconomic and portfolio conditions more than fifteen years ago. Yet, these disparate approaches have not yielded consistent findings regarding the impact of portfolio variables on migrants’ remitting patterns and each is limited in its ability to provide robust evidence on remittance behavior with respect to portfolio values.

\section{Methodology}

Our primary aim is to assess whether remittances respond to portfolio variables -a behavior consistent with the accumulation and rebalancing of asset holdings cross-nationally. As we have noted earlier, the responsiveness of immigrants to portfolio variables does not prevent them from remitting for reasons other than asset accumulation. Nevertheless, the preponderance of certain patterns provides supporting evidence of remittances being sent, at least in part, with a portfolio motive.

We estimate a simple remitting equation that includes portfolio variables and differences in macroeconomic conditions between the home and host country:

$$
R_{i f h r}=\alpha+\beta I_{i}+\gamma F_{f}+\delta P_{h}+\theta_{r}+\varepsilon_{i f h r}
$$

where $R$ is the euro amount remitted last year by immigrant $i$, with family $f$, from home country $h$ and residing in region $r$ in Spain. $I$ is a vector of individual level characteristics, such as gender, age, education, Spanish fluency, time in Spain, work and immigration status. The vector $F$ includes information on family characteristics, such as marital status, the number of children residing in the 
Spanish household, in the home country and elsewhere, information on family reunification plans and on return migration in the next five years, along with information on to whom remittances are sent (e.g. parents, spouse, children or siblings). Additionally, the vector $\theta_{r}$ includes a set of dummy variables indicative of the Spanish region where immigrants reside to address regional differences including cost of living and remittance sending infrastructure- that could contribute toward differences in immigrants’ remitting behavior.

Crucial to our study is $P$, a vector of portfolio and macroeconomic variables capturing economic conditions and portfolio returns in the various home countries included in the study. This vector includes real depreciations of the home currency (vis-à-vis the euro) and real exchange rate volatility. ${ }^{11}$ We also include information on real deposit interest rates and on GDP growth in the countries of origin to further capture how migrants' remitting patterns in our sample vary according to economic conditions at home. ${ }^{12}$ In what follows, we discuss how remittances may respond to the four portfolio variables incorporated into the model.

A) Real Interest Rate: Cross-country differences in real interest rates will change the relative return to financial assets held in the home countries in a very predictable manner. If remitters are concerned about asset returns, remittances would be expected to rise with home real interest rates, ceteris paribus. If immigrants are remitting to simply finance the current consumption needs of family members left behind (such as paying for rent or for food), there is no reason for remittance flows to change in response to an increase in real interest rates relative to rates in other countries.

\footnotetext{
${ }^{11}$ We measure exchange rate volatility using the standard deviation of the monthly log differenced real exchange rate as explained in the Data Appendix.

${ }^{12}$ Note that since Spain is the host country for all migrants in the study, there is no need to incorporate Spanish real interest rates or GDP growth at home and in Spain. The analysis thus examines how remitting motives vary with macroeconomic conditions across countries.
} 
Therefore, the observation that remittances increase with home real interest rates is consistent with the notion that remittances are sent with a portfolio motive.

B) Real GDP growth: Just as with real interest rates, immigrants concerned about the wellbeing of family members back home will send money when economic growth is sluggish at home and reduce their money flows when GDP growth rates are high. Therefore, the observation that remittances respond negatively to GDP growth rates is indicative of remittances taking place for altruistic reasons. In contrast, the observation that remittances respond positively to GDP growth rates is indicative of remittances being sent for investment purposes. Higher GDP growth rates at home signal a growing economy with profitable investment prospects. Therefore, the observation that remittances increase with home GDP growth rates is consistent with the notion that remittances are sent with a portfolio motive.

C) Real Exchange Rate Movements: An understanding of money flows across borders needs to address the potential impact of the real exchange rate. Hence, in addition to real interest rates and GDP growth, we examine immigrants' responses to exchange-rate movements. The real exchange rate is defined as:

$$
\frac{e_{\text {Home currency/euro }} \times P_{\text {Spain }}}{P_{\text {Home }}}
$$

where $e_{\text {Home currency/euro }}$ is the market (or nominal) exchange rate while $P_{\text {Spain }}$ and $P_{\text {Home }}$ are price indexes for the host and home countries, respectively. $P_{\text {Spain }}$ tracks the cost of goods and assets (such as land, housing and durables) in Spain, while $P_{\text {Home }}$ tracks the same in the home country. By multiplying the Spanish price index by the nominal exchange rate, the two price series are expressed in a common currency. Therefore, a rise in the above ratio (real depreciation of the home 
currency or real appreciation of the euro) implies that the cost of goods and the value of physical assets are higher in Spain than in the home country.

How might a Spanish immigrant respond to depreciation of the home currency? Real exchange rate movements will elicit price and wealth effects that tend to influence the sending of remittances in opposite directions. ${ }^{13}$ Unlike real interest rates and GDP growth rates, it is not feasible to decipher from its significance or sign whether the remittances are taking place for altruistic or portfolio reasons. Nevertheless, accounting for the level of the real exchange rate, allows us to more clearly interpret the response of immigrants to real exchange rate volatility -our next portfolio variable.

D) Real Exchange Rate Volatility: Changes in real exchange-rate volatility can definitely impact the investor's perceived riskiness of a given portfolio and elicit a re-organization of her/his assets. This may involve increasing the relative share of home assets by remitting more, or increasing the relative share of Spanish assets by remitting less. Therefore, regardless of its sign, a significant coefficient on exchange rate volatility will be indicative of remittances taking place for portfolio reasons. Once we account for the level of the real exchange rate, there is no reason for remittances sent for altruistic reasons to, for instance, satisfy immediate household needs back home, to vary with exchange-rate volatility.

\footnotetext{
${ }^{13}$ The response to depreciation of the home currency depends on a number of factors. First of all, it depends on whether the immigrant currently owns assets at home, in Spain or, if in both places, on their relative weights in the migrant's portfolio. If the immigrant has assets back home, their value has declined, making the immigrant less wealthy. This wealth effect will likely reduce remittances sent home. If the immigrant, on the other hand, owns assets in Spain, s/he is now wealthier. The increased wealth will increase remittance transfers. Secondly, there is a relative price effect associated with the real exchange rate depreciation. The change in relative prices makes the acquisition of home assets more desirable since it is now relatively cheaper to acquire them. This could induce the immigrant to substitute away from assets held in Spain in favor of assets held in the home country -thereby increasing remittances sent back home for asset accumulation. In sum, it is unclear how real exchange rate depreciation will impact remittances sent home for investment. The price effect should increase remittances sent home, while the wealth effect could affect remittance flows in either direction. However, the more home assets the migrant owns, the more likely the wealth effect will be negative and override the positive price effect, leading to a reduction in remittances.
} 
The estimation of equation (1), which incorporates portfolio variables along with the characteristics of the migrant and his/her family, presents a few challenges. First, one needs to take into account the ongoing selection into remitting and, therefore, the many zeros in our dependent variable. In such cases, an option is to use two-part selection models (e.g. Hoddinott 1994, Funkhouser 1995, Cox et al. 1998). Unfortunately, the results from such models are sensitive to identification exclusions that are debatable given the difficulty of envisioning factors that affect the likelihood of remitting money home, yet have no influence on the remittance amount sent. An alternative in such instances is to use a Tobit model (Brown 1997, Ravallion and Dearden 1998, Schrieder and Knerr 2000). We thus estimate equation (1) as a Tobit model.

Still, there are other challenges. In particular, owing to the cross-sectional nature of our data set, we are unable to control for individual level heterogeneity or for unobservable country-level characteristics possibly biasing our estimates via their correlation to the error term in equation (1). ${ }^{14}$ This drawback hampers our ability to unequivocally claim causality. To address this limitation, in addition to the country-level portfolio variables already discussed, ${ }^{15}$ we include as many individual and family descriptors as possible. Additionally, we cluster standard errors at the migrant's country of origin level and, when lumping all countries together, we include dummies indicative of the region of the world to address any potential heterogeneity according to whether migrants originate from Africa, the Americas or Europe. Finally, we perform a series of step-regressions to explore

\footnotetext{
${ }^{14}$ We are not concerned about reverse causality given the characteristics of the data. Indeed, the micro-economic nature of our data, the diversity of origins in the migrant sample and, more importantly, the fact that Spain is not the main destination country for the most numerous groups of migrants in the sample -Americans and Europeans, limits the possibility that remittances sent from Spain are the cause of changing macroeconomic conditions in the home country.

${ }^{15}$ Note that while other country-level characteristics, such as transaction costs or the reliability and safety of home investments, could drive remittance flows and investment in the home country, they are likely subsumed in the included portfolio variables. For instance, higher transactions costs or default risk would typically lead to higher interest rates.
} 
the direction of any bias incurred by not being able to control for important personal, host country and region of origin characteristics. ${ }^{16}$

\section{Data}

We rely on data from the recent Spanish immigration survey, the Encuesta Nacional de Inmigrantes (ENI). The ENI is a cross-sectional survey carried out by the Spanish Statistical Institute (INE) on foreign-born individuals, at least sixteen years of age, residing in Spain. The INE relied on the municipal population registers to extract a representative sample of the immigrant population. The municipal register or Padrón Municipal provides the most representative immigrant count as registering in it grants immigrants the right to medical and other municipal services. Approximately 15,465 individuals were interviewed over a four-month period running between November 2006 and February 2007. The response rate was 87.4 percent. The survey contains extensive information regarding the demographic characteristics of the migrant and her/his migration experience. Of particular interest to us is the information on the euro amount sent by the migrant during the previous year. ${ }^{17}$

Table 1 displays the average characteristics of all immigrants included in our final analysis. About 45 percent of Spanish immigrants are male and, on average, they are 38 years old and have been in Spain for 11.5 years. Approximately 64 percent are fluent in Spanish and, overall, immigrants are fairly well-educated, with 22 percent reporting tertiary (university) education. Slightly more than half of the sample is married. Sixty-five percent of migrants are employed and

\footnotetext{
${ }^{16}$ Results, available from the authors upon request, indicate that the sign and statistical significance of the key findings remain unaltered when adding these important controls, thus hinting on the robustness of our results.

${ }^{17}$ For more information about the survey, its design and sampling framework, please visit the following webpage: http://www.ine.es/daco/daco42/inmigrantes/inmigra_meto.pdf
} 
93 percent are documented. Finally, a quarter of immigrants plan on bringing family to Spain and about 7 percent expect to return to their home country within five years.

Characteristics of immigrants from Africa, the Americas, the EU and the non-EU European countries are displayed in the last four columns of Table 1 . There is considerable diversity in personal and family migrant characteristics according to their origins. Immigrants from Africa are more likely to be younger and male relative to immigrants from the Americas or Europe. Immigrants from the Americas have arrived more recently. African immigrants are also the least likely to be fluent in Spanish and are the least educated. Americans, on the other hand, are the least likely to be married and the most likely to be undocumented. A higher percentage of them also report planning to return home within the next five years. In contrast, African immigrants are the most likely to have intentions of family reunification in Spain. Overall, it appears that immigrants from the different world regions differ in their personal and family characteristics and on future plans, pointing to their potentially distinct motives for migrating and remitting.

Average remitting rates and the average amount sent by immigrants who remit are reported in Table 2. Immigrants from the Americas seem the most likely to remit, with 54 percent of them doing so in 2006. Immigrants from Europe are much less likely to remit, which suggests that their remitting motives might differ from those of African or American immigrants. Finally, American immigrants are, on average, remitting the largest sums of money.

Who remits? Table 3 addresses this question with a summary of the characteristics of remitters by region of origin. Remitters (as opposed to the general population of immigrants described earlier in Table 1) are generally characterized by having shorter Spanish residencies, higher employment rates and also higher home country asset ownership rates than the average migrant from the same region. Additionally, in the aggregate, remitters are more likely to be 
undocumented, have lower educational attainment and have plans of returning home in the next five years. Yet, we also find that remitters are more likely to claim having plans of family reunification in Spain, thus hinting on the very diverse motives for migrating and remitting in our sample.

In order to determine whether relative macroeconomic conditions impact the remitting patterns of immigrants in our sample, we match 2006 macroeconomic home conditions to each observation in the survey. For example, for immigrants from Argentina, we have information on the average monthly rate of real depreciation of the Argentinean peso against the euro in 2006, on the Argentinean real deposit interest rate in 2006, on Argentinean GDP growth in 2006 and exchange rate volatility of the real Argentinean peso/euro exchange rate -measured as the standard deviation in monthly real exchange rate changes for that currency pair over the year. ${ }^{18}$ Table 4 displays (average over all the countries in each specific region) these economic variables in each region and in Spain in 2006. Relative to Spain, EU member countries experienced real appreciation in 2006. This could be the case if, for example, the rest of the EU nations had higher inflation rates. ${ }^{19}$ Exchange rate volatility vis-à-vis the euro was lowest in the EU and highest for the Americas in 2006. On average, real interest rates were close to zero in Africa, negative in the Americas, a third of a percentage point in the EU and highest in the Non-EU European nations. GDP growth was fastest in the Non-EU European countries and in the Americas. The EU countries experienced the slowest growth. Overall, the figures in Table 4 reflect the wide variety in macroeconomic conditions across the regions covered in this study and raise the possibility that they drive remitting patterns.

\footnotetext{
${ }^{18}$ Please refer to the data appendix for details on the construction of these variables and for information on the macroeconomic data sources.

${ }^{19}$ Official statistics reveal that the inflation rate, on average, of EU countries was 3.2 percent in comparison to Spain's 2.6 percent during 2006.
} 


\section{Findings}

Our goal is to examine whether migrants' remittances respond to cross-country differences in macroeconomic conditions as one might expect if asset accumulation is one of the purposes for remitting. With this aim in mind, we first estimate a Tobit model of the euro amount remitted yearly by all migrants in our sample. Next, we explore the heterogeneity in remitting patterns by assessing how the response of migrant remittances to portfolio variables depends on the length of their migration spell, on their family reunification plans, or on their education as popularly believed. Finally, due to the marked disparities across immigrants from the various regions of origin, we examine differences in immigrants’ remitting behavior disaggregated by place of origin. This analysis allows us to uncover important differences in migrants’ remitting patterns in response to variations in portfolio variables not apparent in the estimations that aggregate all immigrants.

\section{A) Evidence from All Immigrants}

Table 5 presents the coefficients, standard errors and marginal effects for both the likelihood of remitting money home and for the euro amount remitted yearly by migrants using the full sample. The results point to the role played by a variety of personal, family and region of origin characteristics in shaping migrant remittances. Overall, the results conform to previous findings in the literature. For instance, the likelihood of remitting and the euro amount remitted by migrants on a yearly basis is higher for males and immigrants with children back home. Likewise, it is higher for immigrants planning on bringing their families to Spain. Working immigrants are also more likely to remit. After all, their earnings increase their remitting capability. Immigrants with children in Spain remit less. Of particular interest to us is the fact that immigrants who own assets back home are more likely to remit and remit higher sums (all other things equal). Such a finding is consistent with the idea that migrants with assets in the home community have revealed a 
preference for home investment and that remittances are sent to either maintain or increase their stock of home assets (Lucas and Stark, 1985). It could also signify that those immigrants are more tuned into their home communities for a number of reasons. Perhaps, they are responsible for caring for home family or for managing their own home assets. Finally, the figures in Table 5 also reveal how migrants remit more when they plan to return to the home country in the next five years. This could be signaling the desire to maintain their social capital back home. Alternatively, it could be indicative of the fact that they are 'target savers' who remit with the goal of purchasing assets to be used upon their return. In any event, it is interesting to note how the amounts remitted home vary with the relationship of the remitter to the receiver of the money flows. Remittances flows sent to parents and children exceed those sent to partners by approximately 400 euros and 200 euros per year, respectively. Remitters appear least generous with respect to siblings.

Do migrant remittances respond to the macroeconomic variables being examined in a manner indicative of the existence of a portfolio motive? The answer is yes. In addition to responding to cross-country variation in the level of the real exchange rate, ${ }^{20}$ which is a response consistent with remittance transfers sent for asset accumulation and altruistic purposes, remittances also respond to exchange rate volatility. A doubling of exchange rate volatility is associated with a 3.6 percentage point increase in the likelihood of remitting $(0.018 \times 1.98=0.036)$. This increase in volatility seems to cause immigrants to reassess their transnational portfolio of assets and increase their remittance flows (and, thus, home assets) by 45 euros/year. In sum, as with migration, migrant remittances are motivated by various factors, including relative macroeconomic conditions and portfolio variables.

\footnotetext{
${ }^{20}$ Migrants remit less when the home currency depreciates. Specifically, a doubling of the real exchange rate (real depreciation of 100 percent) lowers the likelihood of remitting by 8.8 percentage points (from 34 percent to about 25 percent) and the amount remitted by 112 euros per year (from 1734 euros/year to 1622 euros/year) or by approximately 6 percent.
} 


\section{B) Heterogeneity in Remitting Patterns}

Before proceeding any further, we examine how the response of remittance flows to portfolio variables varies with immigrant characteristics known to be crucial in shaping remittance flows -such as the duration of the migration spell, family reunification plans or educational attainment. The results from this exercise are displayed in Tables 6 and 7.

As shown by the figures in the upper panel of Table 6, longer migration spells heighten the response of remittances to GDP growth rates back home, ${ }^{21}$ real exchange rate depreciations and increases in real exchange rate volatility as indicated by the statistically significant signs of the interaction terms. Take, for instance, a doubling of the real exchange rate (i.e. a home currency depreciation of 100\%). The latter reduces migrants' remitting likelihood by 6 percentage points and the amount remitted by 72 euros/year. Yet, the impact is much larger among immigrants with migration spells lasting 10 years. Their probability of remitting declines by 10 percentage points ($0.059-(10 \times 0.004)=-0.099)$ and their remittance flow drops by 122 euros/year.

In the same vein, a doubling of real exchange rate volatility increases the likelihood of remitting by 0.2 percentage points $(0.12 \times 0.018=0.002)$. This effect increases to 4.5 percentage points when the migration spell reaches 10 years (or: $0.002+(0.245 \times 1090.018)=0.045)$.

Finally, a 5 percentage-point increase in home growth initially results in a 3 percentagepoint decrease in the likelihood of remitting $(5 \mathrm{x}-0.006=-0.03)$ and a reduction in the size of the remittance flow of about 37 euros/year. Yet, the same increase in home growth results in a 7 percentage-point increase $(-0.03+(10 \times 5) \times 0.002=0.07)$ in the likelihood of remitting and in an increase in the size of the remittance flow of 100 euros/year $(-37+(10 \times 5)$ x $2.012=100)$ as the migration spell reaches 10 years. This last result is interesting as it suggests that immigrants'

\footnotetext{
${ }^{21}$ The F-test for the joint significance of the GDP Growth Rate and Time in Spain*GDP Growth Rate coefficients indicates that they are highly significant at the 1 percent level.
} 
remittances are originally consistent with altruism. Nevertheless, over time, immigrants' remitting becomes increasingly more responsive to portfolio considerations. Instead of remitting in response to poorer economic conditions back home, immigrants' remittances appear to increase with strong economic growth back home and become more sensitive to the level of the real exchange rate and its volatility. It is conceivable that when migrants initially migrate, they do so for pressing economic reasons. As a result, remittances are initially geared toward smoothing household income and consumption back home. However, over time, as the family's pressing needs have been addressed and migrants become settled in the host economy, remittances may be primarily intended for asset accumulation with the purpose of meeting long-term economic goals, including greater economic stability. This may be why portfolio-driven remittances appear more likely to take place among migrants with longer migration spells.

The figures in the bottom panel of Table 6 display the results from repeating the same exercise focusing on variations in the impact of portfolio variables on remittance flows according the migrant's family reunification plans. Not surprisingly, when migrants plan on bringing family to Spain, they become less responsive to GDP growth rates at home and to exchange rate volatility. Indeed, while higher growth rates at home increase the remitting likelihood and the amount remitted by migrants, these impacts are weaker when they plan on bringing their families to Spain. Similarly, the impact of exchange rate volatility on migrants' remitting behavior weakens if they have family reunification plans. For instance, a doubling of real exchange rate volatility from its mean rate of about 0.018 to 0.036 is associated with a 5 percentage point increase in the likelihood of remitting $(2.960 \times 0.018=0.053)$ and, conditioned on remitting, with an increase in remittance flows of approximately 67 euros/year (3729 x 0.018). However, for migrants with family reunification plans, a doubling of exchange rate volatility increases the likelihood of remitting by 
only 1.5 percentage points $(2.96-2.10)$ x $0.018=0.015$ and the amount remitted by 19 euros/year. Perhaps, in this case, remitters are more focused on simply amassing a target sum to pay for the travel of family members.

Lastly, we differentiate immigrants according to their educational attainment to assess if the response to portfolio variables is unique to the highly educated, as it is often popularly stated. We estimate two regressions, one including immigrants with a university (or tertiary) education and another one including less educated immigrants. Table 7 displays the results from this exercise. In some respects, the response of remittance flows to portfolio variables does vary according to immigrants' educational attainment. The remittance flows from more educated immigrants appear responsive to real exchange rate depreciations, while those of their less educated counterparts are more responsive to GDP growth rates. Yet, remittance flows respond similarly to increases in real exchange rate volatility regardless of the sender's educational attainment. Therefore, remittances do vary according to macroeconomic and portfolio variables regardless of the educational attainment of the sender, even if there is variation in the subset of variables they respond to. This could be due to the type of assets both sets of immigrants accumulate. For example, if one group mainly invests in housing and the other in financial assets, it is conceivable that the two groups might respond differently to the various macroeconomic variables being considered.

\section{C) Evidence by Region of Origin}

We saw earlier that the characteristics of immigrants and remitters from the various regions of the world differ. Therefore, remitting motives and the responsiveness of remittance flows to relative macroeconomic variables might also differ. If that is the case, grouping all countries together might only obscure the role played by cross-country variations in portfolio variables in shaping remittance flows. Hence, we rerun the analysis distinguishing immigrants according to 
their region of origin. Table 8 displays the results for the key macroeconomic variables object of interest.

African immigrants respond positively to high real interest rates back home, whereas none of the other country groups do. In the same vein, American immigrants decrease remittances with real exchange rate depreciation, while none of the other groups do. Additionally, American immigrants are less likely to remit when home growth rates are high, whereas EU migrants tend to remit home when home growth rates are high. All groups, except for Africans, remit more when there is greater volatility in the real exchange rate.

In sum, portfolio motive appear to be present for all immigrants regardless of their origin. Yet, there are regional differences in the variables that remitters appear to be responding to -a pattern consistent with regional variations in migrating and remitting motives. Evidence of altruism is most clearly seen in the immigrants originating in the Americas as displayed by the negative and statistically significant coefficient on GDP growth. Yet, Americans also respond to changes in exchange rate volatility, suggesting that portfolio variables also matter to them. Africans, EU and non-EU European migrants also display responsiveness to portfolio variables. Africans step up their remitting when real interest rates rise, Europeans do so when faced with higher exchange rate volatility and, in the case of Europeans from EU members, remitting further rises with GDP growth rates at home.

\section{Summary and Conclusions}

Migration takes place for many reasons. Some people migrate in search of better working opportunities. Some migrate to acquire human capital. Yet, others migrate in order to accumulate retirement or business assets, to escape political or religious persecution or for family reunification purposes. Consequently, it should not come as a surprise that remittances -the earnings that 
immigrants send home- might also be sent for a plethora of motives. Given this diversity, it is not possible to unequivocally assign a single motive for remittance flows.

In this study, we find that remittances appear to respond to both portfolio and non-portfolio variables. From this finding, we infer that remittances are sent for many different reasons. One such reason may be to engage in asset accumulation. This is a behavior possibly motivated by emigrants' desire to smooth their consumption during difficult times in their host communities $-\mathrm{a}$ challenging goal for immigrants with difficult access to credit or originating from countries with incomplete credit markets. We find that the response to the various portfolio variables becomes stronger, the longer the migrants have resided in the host community. The pattern observed is suggestive of an evolution of motives, pointing toward remitting for asset accumulation over time.

When we disaggregate by region of origin, immigrants from the Americas provide the most evidence that remitters are altruistically motivated by responding to slow home growth, while also showing evidence of responding to portfolio variables. European migrants also seem to react to portfolio variables. They step up their remitting as real exchange rate volatility rises and, in the case of Europeans from EU member countries, remittances further increase in response to economic growth. Finally, remittances from African migrants also seem to respond to portfolio motives, rising with real interest rate levels.

In sum, remittance flows are responsive to cross-country differences in portfolio variables in a manner consistent with the accumulation of assets transnationally. Knowledge of the determinants of remittances is crucial for understanding observed fluctuations in such flows. This study underscores the complexity of remittance patterns, which not only vary with migrants' origin, but also with their family reunification plans and the length of their migration spell. 


\section{References}

Adams Jr., Richard H. 2005. "Remittances, Household Expenditures and Investment in Guatemala”, World Bank Policy Research Working Paper No. 3532.

Airola, Jim. 2007. "The Use of Remittance Income in Mexico”, International Migration Review 41(4): 850-59.

Amuedo-Dorantes, Catalina and Francesca Mazzolari. 2010. "Remittances to Latin America from migrants in the United States: Assessing the impact of amnesty programs”, Journal of Development Economics, 91(2): 323-335.

Brown, Richard P.C. 1994. "Migrants' Remittances, Savings and Investment in the South Pacific”, International Labour Review, 133(3): 347-367.

Bugamelli, Matteo, and Francesco Paterno. 2005. "Do workers' remittances reduce the probability of current account reversals?”, World Bank Policy Research Working Paper no. 3766.

Faini, Riccardo. 1994. "Workers' Remittances and the Real Exchange Rate: A quantitative Framework”, Journal of Population Economics, 7: 235-45.

Gammage, Sarah. 2007. “Gender and Transnational Asset Accumulation in El Salvador” in Moser, Caroline, ed. Reducing Global Poverty: The Case for Asset Accumulation. Washington D.C. Brookings Institution Press, pp. 255-272.

Higgins, Matthew, Alketa Hysenbegasi and Susan Pozo. 2004. "Exchange-Rate Uncertainty and Workers' Remittances”, Applied Financial Economics, 14(6): 403-411.

Lanzieri, Giampaolo and Veronica Corsini. 2006. Statistics in Focus: Population and Social Conditions. Eurostat. Available at: http://epp.eurostat.ec.europa.eu/cache/ITY_OFFPUB/KS-NK06-001/EN/KS-NK-06-001-EN.PDF

Leland, Hayne, E. 1968. "Saving and Uncertainty: The Precautionary Demand for Saving”, Quarterly Journal of Economics, 82: 465-73.

Lianos, Theodore P. 1997. "Factors Determining Migrant Remittances: the Case of Greece", International Migration Review, 31(1): 72-87.

Lucas, Robert E. B. and Oded Stark. 1985. “Motivations to Remit: Evidence from Botswana”, Journal of Political Economy, 93(5): 901-18.

Modigliani, Franco and Richard Brumberg. 1954. "Utility Analysis and the Consumption Function: An Interpretation of Cross-Section Data” in K.K. Kurihara, ed, Post-Keynesian Economics, Rutgers University Press, New Brunswick, N.J. pp. 388-436. 
Ortega Pérez, Nieves. 2003. “Spain: Forging an Immigration Policy”, Migration Policy Institute, available at: http://www.migrationinformation.org/feature/display.cfm?ID=97

Pozo, Susan and Carlos Vargas-Silva. 2006. “Do Immigrants and their Remittances Respond to the Exchange Rate?”, Unpublished manuscript.

Ratha, Dilip. 2004. “Workers' Remittances: An Important and Stable Source of Development Finance”, Global Development Finance, pp. 157-175.

Ratha, Dilip and William Shaw. 2007. “South-South Migration and Remittances”, World Bank Working Paper No. 102.

Roberts, Debra. 2009. “The Development Impact of Remittances on Guyana’s Economy”, Social and Economic Studies, 58(3\&4): 199-225.

Rosenzweig, Mark R and Oded Stark. 1989. “Consumption Smoothing, Migration, and Marriage: Evidence from Rural India”, Journal of Political Economy, 97: 905-26.

Stahl, Charles V and Fred Arnold. 1986. “Overseas Workers' Remittances in Asian Development”, International Migration Review, 20(4): 899-925.

Taghavi, Majid. 2012. "The impact of workers remittances on Macroeconomic Indicators: The case of the Gulf Cooperation Council”, Topics in Middle Eastern and African Economies, 14(September): 49-73.

Taylor, J. Edward and Jorge Mora. 2006. "Does Migration Reshape Expenditures in Rural Households?”, World Bank Policy Research Working Paper No. 3842.

Yang, Dean. 2008. "International Migration, Remittances and Household Investment: Evidence from Philippine Migrants’ Exchange Rate Shocks”, Economic Journal, 118(April): 591-630.

Zarate-Hoyos, German A. 2004. "Consumption and Remittances in Migrant Households: Toward a Productive Use of Remittances”, Contemporary Economic Policy, 22 (4): 555-65.

World Bank. 2011. Migration and Remittances Factbook 2011, $2^{\text {nd }}$ Edition. Available at: http://siteresources.worldbank.org/INTLAC/Resources/Factbook2011-Ebook.pdf 
Table 1: Characteristics of Immigrants by Continent of Origin

\begin{tabular}{|c|c|c|c|c|c|}
\hline Variables & All & Africa & Americas & $\begin{array}{c}\text { EU } \\
\text { Members }\end{array}$ & $\begin{array}{c}\text { Europe } \\
\text { Non-EU } \\
\text { Members }\end{array}$ \\
\hline Male & 0.45 & 0.63 & 0.39 & 0.45 & 0.42 \\
\hline Age (in years) & 37.68 & 32.48 & 34.22 & 41.52 & 36.24 \\
\hline Time in Spain (in years) & 11.49 & 8.13 & 5.80 & 16.06 & 13.11 \\
\hline Fluent in Spanish & 0.64 & 0.27 & 0.96 & 0.51 & 0.49 \\
\hline Primary Education or Less & 0.19 & 0.36 & 0.20 & 0.17 & 0.09 \\
\hline Secondary Education & 0.59 & 0.54 & 0.60 & 0.59 & 0.54 \\
\hline Tertiary Education & 0.22 & 0.09 & 0.20 & 0.24 & 0.37 \\
\hline Married & 0.53 & 0.63 & 0.45 & 0.57 & 0.50 \\
\hline Children in Spain & 0.69 & 0.65 & 0.67 & 0.75 & 0.49 \\
\hline Children Abroad & 0.33 & 0.20 & 0.45 & 0.29 & 0.25 \\
\hline Employed & 0.65 & 0.58 & 0.71 & 0.62 & 0.68 \\
\hline Undocumented & 0.07 & 0.10 & 0.16 & 0.00 & 0.07 \\
\hline HC Asset Ownership & 0.25 & 0.20 & 0.31 & 0.21 & 0.35 \\
\hline Plans on Returning Home & 0.07 & 0.04 & 0.13 & 0.05 & 0.03 \\
\hline Plans on Bringing the Family & 0.24 & 0.48 & 0.39 & 0.09 & 0.14 \\
\hline Remits to Parents & 0.22 & 0.35 & 0.34 & 0.11 & 0.15 \\
\hline Remits to Partner & 0.03 & 0.07 & 0.04 & 0.01 & 0.03 \\
\hline Remits to Children & 0.09 & 0.07 & 0.16 & 0.04 & 0.09 \\
\hline Remits to Siblings & 0.07 & 0.14 & 0.12 & 0.03 & 0.05 \\
\hline Remits to Other Family & 0.04 & 0.03 & 0.07 & 0.03 & 0.04 \\
\hline Remits to Others & 0.01 & 0.01 & 0.01 & 0.01 & 0.01 \\
\hline $\mathrm{N}$ & 8,743 & 942 & 2,969 & 4,216 & 573 \\
\hline
\end{tabular}

Table 2: Remittances by Continent of Origin

\begin{tabular}{lccc}
\hline \hline Area of Origin & $\begin{array}{c}\text { Number of } \\
\text { Observations }\end{array}$ & Proportion Who Remits & $\begin{array}{c}\text { Amount Remitted in } \\
\text { euros (last year) }^{\mathbf{a}}\end{array}$ \\
\hline All Immigrants & 8,743 & 0.34 & 1,734 \\
Africa & 942 & 0.45 & 1,368 \\
America & 2,969 & 0.54 & 1985 \\
EU Members & 4,216 & 0.18 & 1,458 \\
Europe Non-EU Members & 573 & 0.27 & 1,494 \\
\hline \hline
\end{tabular}

Notes: (a) Average amount remitted conditional on remitting a positive sum last year. 
Table 3: Characteristics of Remitters by Continent of Origin ${ }^{a}$

\begin{tabular}{|c|c|c|c|c|c|}
\hline Personal Migrant Characteristics & All & Africa & Americas & $\underset{\text { Members }}{\text { EU }}$ & $\begin{array}{c}\text { Europe } \\
\text { Non-EU } \\
\text { Members }\end{array}$ \\
\hline Male & 0.46 & 0.76 & 0.39 & 0.48 & 0.39 \\
\hline Age & 34.61 & 33.89 & 34.41 & 34.68 & 37.99 \\
\hline Time in Spain & 5.70 & 7.77 & 5.38 & 5.22 & 5.82 \\
\hline Fluent in Spanish & 0.68 & 0.25 & 0.97 & 0.39 & 0.23 \\
\hline Primary Education or Less & 0.20 & 0.36 & 0.21 & 0.13 & 0.06 \\
\hline Secondary Education & 0.64 & 0.54 & 0.64 & 0.73 & 0.52 \\
\hline Tertiary Education & 0.15 & 0.10 & 0.15 & 0.13 & 0.43 \\
\hline Married & 0.52 & 0.65 & 0.45 & 0.57 & 0.61 \\
\hline Children in Spain & 0.57 & 0.52 & 0.61 & 0.55 & 0.45 \\
\hline Children Abroad & 0.54 & 0.36 & 0.67 & 0.37 & 0.56 \\
\hline Employed & 0.79 & 0.74 & 0.81 & 0.78 & 0.82 \\
\hline Undocumented & 0.09 & 0.07 & 0.14 & 0.00 & 0.10 \\
\hline HC Asset Ownership & 0.38 & 0.28 & 0.35 & 0.44 & 0.69 \\
\hline Plans on Returning Home & 0.12 & 0.04 & 0.16 & 0.12 & 0.04 \\
\hline Plans on Bringing the Family & 0.50 & 0.66 & 0.56 & 0.30 & 0.38 \\
\hline Remits to Parents & 0.64 & 0.80 & 0.63 & 0.62 & 0.54 \\
\hline Remits to Partner & 0.08 & 0.16 & 0.07 & 0.06 & 0.10 \\
\hline Remits to Children & 0.26 & 0.15 & 0.29 & 0.22 & 0.34 \\
\hline Remits to Siblings & 0.21 & 0.31 & 0.21 & 0.16 & 0.18 \\
\hline Remits to Other Family & 0.13 & 0.07 & 0.13 & 0.14 & 0.15 \\
\hline Remits to Others & 0.03 & 0.02 & 0.02 & 0.05 & 0.04 \\
\hline $\mathrm{N}$ & 2,973 & 424 & 1,603 & 759 & 155 \\
\hline
\end{tabular}

Table 4: Macroeconomic Conditions in the Continent of Origin and in Spain in 2006

\begin{tabular}{lccccc}
\hline \hline Macroeconomic Conditions & Africa & Americas & $\begin{array}{c}\text { EU } \\
\text { Members }\end{array}$ & $\begin{array}{c}\text { Europe } \\
\text { Non-EU } \\
\text { Members }\end{array}$ & Spain \\
\hline Real Exchange Rate Depreciation (monthly average) & 0.0018 & 0.0455 & -0.0023 & 0.0015 & NA \\
Real Exchange Rate Volatility & 0.0114 & 0.0317 & 0.0104 & 0.0126 & NA \\
Real Interest Rate & 0.1907 & -0.3121 & 0.3557 & 1.3113 & 2.35 \\
GDP Growth Rate & 5.2528 & 4.5758 & 3.7667 & 5.8020 & 2.16 \\
\hline \hline
\end{tabular}

Notes: The exchange rate is defined as home currency units per euro. Hence, a rise indicated depreciation for the home currency or appreciation of the Euro. See appendix for details about the measurement of real exchange rate changes. 
Table 5: Tobit Model of the Euro Amount Remitted Yearly by All Immigrants

\begin{tabular}{|c|c|c|c|c|}
\hline \multirow{2}{*}{ Independent Variables } & \multicolumn{4}{|c|}{ Euro Amount Remitted Yearly } \\
\hline & Coefficient & S.E. & $\begin{array}{c}\text { M.E. on } \\
\text { Prob }(Y>0)\end{array}$ & $\begin{array}{c}\text { M.E. on } \\
\mathbf{E}(\mathbf{Y} \mid \mathbf{Y}>0) \\
\end{array}$ \\
\hline Male & $137.900 * *$ & 58.529 & 0.019 & 24.646 \\
\hline Age & 3.260 & 4.545 & 4.57E-04 & 0.579 \\
\hline Time in Spain & -21.747 & 27.934 & -0.003 & -3.864 \\
\hline Time in Spain Squared & -0.493 & 1.112 & $-6.92 E-05$ & -0.088 \\
\hline Fluent in Spanish & 21.728 & 76.327 & 0.003 & 3.851 \\
\hline Secondary Education & 76.995 & 72.252 & 0.011 & 13.608 \\
\hline Tertiary Education & -163.825 & 126.273 & -0.022 & -28.047 \\
\hline Married & -32.365 & 72.141 & -0.005 & -5.755 \\
\hline Children in Spain & $-53.498 *$ & 31.225 & -0.008 & -9.505 \\
\hline Children Abroad & $157.290 *$ & 83.496 & 0.022 & 27.946 \\
\hline Employed & $453.844 * * *$ & 74.037 & 0.061 & 76.598 \\
\hline Undocumented & -10.537 & 201.597 & -0.001 & -1.865 \\
\hline HC Asset Ownership & $544.808 * * *$ & 62.769 & 0.082 & 108.116 \\
\hline Plans on Returning Home & $519.046 * * *$ & 178.515 & 0.081 & 109.614 \\
\hline Plans on Bringing the Family & $397.795 * * *$ & 79.838 & 0.059 & 76.841 \\
\hline Remits to Parents & $2,859.670 * * *$ & 106.284 & 0.507 & 937.616 \\
\hline Remits to Partner & $1,753.166^{* * *}$ & 333.552 & 0.327 & 565.600 \\
\hline Remits to Children & $2,227.313^{* * *}$ & 247.701 & 0.417 & 767.911 \\
\hline Remits to Siblings & $1,385.833^{* * *}$ & 146.950 & 0.245 & 384.316 \\
\hline Remits to Other Family & $2,417.158 * * *$ & 177.157 & 0.463 & 916.971 \\
\hline Remits to Other Individuals & $2,866.554 * * *$ & 519.446 & 0.554 & $1,262.084$ \\
\hline Africa & -424.465 & 345.543 & -0.055 & -66.216 \\
\hline EU Members & -487.420 & 313.033 & -0.068 & -86.772 \\
\hline Europe Non-EU Members & $-711.046^{* *}$ & 306.811 & -0.084 & -97.993 \\
\hline GDP Growth Rate & 41.290 & 27.712 & 0.006 & 7.336 \\
\hline Real Interest Rate & -1.032 & 23.272 & $-1.45 \mathrm{E}-04$ & -0.183 \\
\hline Real Exchange Rate Depreciation & $-629.878 * * *$ & 67.942 & -0.088 & -111.912 \\
\hline Real Exchange Rate Volatility & $14,097.690 *$ & $8,186.341$ & 1.978 & $2,504.761$ \\
\hline Spanish Region of Residence Dummies & \multicolumn{4}{|c|}{ Yes } \\
\hline No. of Observations: & \multicolumn{4}{|c|}{8,339} \\
\hline Uncensored Observations & \multicolumn{4}{|c|}{2,775} \\
\hline Log Pseudo-likelihood & \multicolumn{4}{|c|}{$-25,679.565$} \\
\hline
\end{tabular}

Notes: ***Significant at the 1 percent level or better, **significant at 5 percent level or better and *significant at the 10 percent level or better. Regressions include a constant term and region dummies. Standard errors are clustered at the country of origin level. We use immigrants from the American continent as the reference category. 
Table 6: Tobit Model of the Euro Amount Remitted Yearly by All Immigrants with Additional Interaction Terms

\begin{tabular}{|c|c|c|}
\hline \multirow{2}{*}{ Independent Variables } & \multicolumn{2}{|c|}{ Interactions with Time In Spain } \\
\hline & M.E. on $\mathbf{P}(\mathbf{Y}>0)$ & M.E. on E(Y|Y>0) \\
\hline Time in Spain & $-0.016 * * *$ & $-19.255^{* * *}$ \\
\hline Time in Spain Squared & 2.42E-05 & 0.029 \\
\hline GDP Growth Rate & -0.006 & -7.409 \\
\hline Real Interest Rate & -0.001 & -0.615 \\
\hline Real Exchange Rate Depreciation & $-0.059 * * *$ & $-71.668 * * *$ \\
\hline Real Exchange Rate Volatility & 0.121 & 146.525 \\
\hline Time in Spain*GDP Growth Rate & $0.002 * * *$ & $2.012 * * *$ \\
\hline Time in Spain*Real Interest Rate & 0.0002 & 0.266 \\
\hline Time in Spain*Real Exchange Rate Depreciation & $-0.004 * * *$ & $-5.018 * * *$ \\
\hline Time in Spain*Real Exchange Rate Volatility & $0.248 * * *$ & $300.320 * * *$ \\
\hline No. of Observations & & \\
\hline Uncensored Observations & & \\
\hline Log Pseudo-likelihood & & \\
\hline \multirow{2}{*}{ Independent Variables } & \multicolumn{2}{|c|}{ Interactions with Plans on Bringing Family } \\
\hline & M.E. on $\mathbf{P}(\mathbf{Y}>\mathbf{0})$ & M.E. on $\mathbf{E}(\mathbf{Y} \mid \mathbf{Y}>\mathbf{0})$ \\
\hline Plans on Bringing Family & $0.185^{* * *}$ & $260.929 * * *$ \\
\hline GDP Growth Rate & $0.009 *$ & 11.589* \\
\hline Real Interest Rate & -0.001 & -1.020 \\
\hline Real Exchange Rate Depreciation & $-0.091 * * *$ & $-114.162 * * *$ \\
\hline Real Exchange Rate Volatility & $2.960 * * *$ & $3,729.185^{* * *}$ \\
\hline Plans on Bringing Family*Per capita GDP & $-0.010 *$ & $-12.999 *$ \\
\hline Plans on Bringing Family*Real Interest Rate & 0.002 & 2.317 \\
\hline Plans on Bringing Family*Real Exchange Rate Depreciation & -0.015 & -19.334 \\
\hline Plans on Bringing Family*Real Exchange Rate Volatility & $-2.102 * *$ & $-2,647.942 * *$ \\
\hline No. of Observations & \multicolumn{2}{|c|}{8,339} \\
\hline Uncensored Observations & \multicolumn{2}{|c|}{2,775} \\
\hline Log Pseudo-likelihood & \multicolumn{2}{|c|}{$-25,671.332$} \\
\hline
\end{tabular}

Notes: Full regression results, including coefficients and standard errors, are available from the authors. ***Significant at the 1 percent level or better, ${ }^{* *}$ significant at 5 percent level or better and *significant at the 10 percent level or better. Regressions include a constant term and all other regressors in Table 5. Standard errors are clustered at the country of origin level. 
Table 7: Tobit Models for the Euro Amount Remitted Yearly by Immigrants' Educational Attainment

\begin{tabular}{|c|c|c|c|c|}
\hline \multirow{2}{*}{ Independent Variables } & \multicolumn{2}{|c|}{ "Tertiary Education } & \multicolumn{2}{|c|}{ "Less than Tertiary Education } \\
\hline & M.E. on $P(Y>0)$ & M.E. on $\mathrm{E}(\mathrm{Y} \mid \mathrm{Y}>\mathbf{0})$ & M.E. on $\mathbf{P}(\mathbf{Y}>\mathbf{0})$ & M.E. on $\mathrm{E}(\mathrm{Y} \mid \mathrm{Y}>0)$ \\
\hline GDP Growth Rate & 0.001 & 0.844 & $0.006^{*}$ & $7.984 *$ \\
\hline Real Interest Rate & -0.001 & -0.771 & $-1.85 E-04$ & -0.233 \\
\hline Real Exchange Rate Depreciation & $-0.047 * * *$ & $-47.857 * * *$ & $-0.116^{* * *}$ & $-145.868 * * *$ \\
\hline Real Exchange Rate Volatility & $3.844 * * *$ & $3,912.491 * * *$ & 1.173 & 1480.700 \\
\hline No. of Observations & \multicolumn{2}{|c|}{1,764} & \multicolumn{2}{|c|}{6,575} \\
\hline Uncensored Observations & \multicolumn{2}{|c|}{383} & \multicolumn{2}{|c|}{2,392} \\
\hline Log Pseudo-likelihood & \multicolumn{2}{|c|}{$-3,575.292$} & \multicolumn{2}{|c|}{$-22,055.515$} \\
\hline
\end{tabular}

Notes: Full regression results, including coefficients and standard errors, are available from the authors. ***Significant at the 1 percent level or better, **significant at 5 percent level or better and *significant at the 10 percent level or better. Regressions include a constant term and all other regressors in Table 5 . Standard errors are clustered at the country of origin level. 
Table 8: Tobit Models for the Euro Amount Remitted Yearly by Immigrants' Region of Origin

\begin{tabular}{|c|c|c|c|c|}
\hline \multirow{2}{*}{ Independent Variables } & \multicolumn{2}{|c|}{ Africa } & \multicolumn{2}{|c|}{ America } \\
\hline & M.E. on $P(Y>0)$ & M.E. on E(Y $\mid Y>0)$ & M.E. on $P(Y>0)$ & M.E. on $E(Y \mid Y>0)$ \\
\hline GDP Growth Rate & 0.019 & 20.123 & $-0.027 * * *$ & $-61.597 * * *$ \\
\hline Real Interest Rate & $0.053^{*}$ & $57.101 *$ & 0.001 & 2.037 \\
\hline Real Exchange Rate Depreciation & $34.870 *$ & $37,462.350 *$ & $-0.158 * * *$ & $-360.252 * * *$ \\
\hline Real Exchange Rate Volatility & -0.945 & $-1,014.776$ & $2.767 * * *$ & $6319.730 * * *$ \\
\hline No. of Observations & \multicolumn{2}{|c|}{927} & \multicolumn{2}{|c|}{2,869} \\
\hline Uncensored Observations & \multicolumn{2}{|c|}{405} & \multicolumn{2}{|c|}{1,547} \\
\hline Log Pseudo-likelihood & \multicolumn{2}{|c|}{$-3,535.511$} & \multicolumn{2}{|c|}{$-14,289.089$} \\
\hline \multirow{2}{*}{ Independent Variables } & \multicolumn{2}{|c|}{ EU Members } & \multicolumn{2}{|c|}{ Europe Non-EU Members } \\
\hline & M.E. on $\mathbf{P}(\mathbf{Y}>0)$ & M.E. on E(Y $\mid Y>0)$ & M.E. on $P(Y>0)$ & M.E. on $P(Y>0)$ \\
\hline GDP Growth Rate & $0.007^{*}$ & $6.259 *$ & $-3.07 E-05$ & -0.010 \\
\hline Real Interest Rate & -0.004 & -3.253 & 1.91E-05 & 0.006 \\
\hline Real Exchange Rate Depreciation & 1.262 & $1,092.892$ & -0.009 & -3.019 \\
\hline Real Exchange Rate Volatility & $1.515^{*}$ & $1,311.852 *$ & $0.061^{* * *}$ & $20.857 * * *$ \\
\hline No. of Observations & \multicolumn{2}{|c|}{4,128} & \multicolumn{2}{|c|}{415} \\
\hline Uncensored Observations & \multicolumn{2}{|c|}{752} & \multicolumn{2}{|c|}{71} \\
\hline Log Pseudo-likelihood & \multicolumn{2}{|c|}{$-6,963.586$} & \multicolumn{2}{|c|}{-629.313} \\
\hline
\end{tabular}

Notes: Full regression results, including coefficients and standard errors, are available from the authors. ***Significant at the 1 percent level or better, **significant at 5 percent level or better and *significant at the 10 percent level or better. Regressions include a constant term and all other regressors in Table 5. Standard errors are clustered at the country of origin level. All of the marginal effects are evaluated at the country mean except for Africa, in which case real exchange rate depreciation of 3 percent was assumed (a global mean). 


\section{APPENDIX TABLES}

\section{Table A: Variable Names and Definitions}

\begin{tabular}{|c|c|}
\hline Variable Names & Definitions \\
\hline Likelihood of Remitting & Migrant remits money home \\
\hline Euro Amount Remitted Yearly & Euro amount remitted last year if they remitted money home \\
\hline Male & Respondent’s gender dummy \\
\hline Age & Respondent's age \\
\hline Time in Spain & Years in Spain \\
\hline Time in Spain Squared & Years in Spain squared \\
\hline Fluent in Spanish & Migrant is fluent in Spanish \\
\hline No Education & Migrant has no education \\
\hline Primary Education & Migrant has a primary school education \\
\hline Secondary Education & Migrant has a secondary school education \\
\hline Tertiary Education & Migrant has purchased university studies \\
\hline Employed & Employment status dummy \\
\hline Undocumented & Legal status dummy \\
\hline HC Asset Ownership & Migrant owns assets (housing, land, cattle, business, autos) in home country \\
\hline Married & Respondent's marital status dummy \\
\hline Children in Spain & Number of children in Spain \\
\hline Children Abroad & Number of children abroad \\
\hline Plans on Returning Home & Migrants plans on returning to her/his home country in the next five years \\
\hline Plans on Bringing the Family & Migrant intends to bring some family members to Spain \\
\hline Remits to Parents & Migrant remits money to parents \\
\hline Remits to Partner & Migrant remits money to a partner \\
\hline Remits to Children & Migrant remits money to children \\
\hline Remits to Siblings & Migrant remits money to siblings \\
\hline Remits to Other Family & Migrant remits money to other family \\
\hline Remits to Other Individuals & Migrant remits money to other individuals \\
\hline Africa & Respondent's continent of birth \\
\hline America & Respondent's continent of birth \\
\hline EU Members & $\begin{array}{l}\text { EU-27 members: Austria, Belgium, Bulgaria, Czech Republic, Cyprus, Denmark, Finland, Estonia, France, Germany, Greece, } \\
\text { Hungry, Ireland, Italy, Latvia, Lithuania, Luxembourg, Malta, Netherlands, Poland, Portugal, Romania, Slovakia, Slovenia, } \\
\text { Spain, Sweden, UK. }\end{array}$ \\
\hline Europe Non-EU Members & $\begin{array}{l}\text { Albania, Armenia, Belorussia, Bosnia-Herzegovina, Croatia, Georgia, Leetonia, Macedonia, Moldova, Montenegro, Norway, } \\
\text { Serbia, Switzerland, Russia, Ukraine. }\end{array}$ \\
\hline GDP Growth Rate & Per capita GDP growth rate in home country in 2006 \\
\hline Real Interest Rate & Real interest rate in home country in 2006 \\
\hline Real Exchange Rate Depreciation & Average of monthly real exchange rate depreciations during 2006 \\
\hline Real Exchange Rate Volatility & Standard deviation of monthly real exchange rate depreciations during 2006 \\
\hline
\end{tabular}


Table B: Means and Standard Deviations of Variables Used in the Analysis

\begin{tabular}{lcc}
\hline \hline Variable Names & Mean & S.D. \\
\hline Likelihood of Remitting & 0.34 & 0.47 \\
Euro Amount Remitted (if they remitted) & 1,734 & 1,820 \\
Independent Variables & & \\
Male & 0.45 & 0.50 \\
Age & 37.68 & 13.40 \\
Time in Spain & 11.49 & 12.30 \\
Fluent in Spanish & 0.64 & 0.48 \\
Primary Education or Less & 0.19 & 0.39 \\
Secondary Education & 0.59 & 0.49 \\
Tertiary Education & 0.22 & 0.41 \\
Married & 0.53 & 0.50 \\
Children in Spain & 0.69 & 1.02 \\
Children Abroad & 0.33 & 0.84 \\
Employed & 0.65 & 0.48 \\
Undocumented & 0.07 & 0.26 \\
HC Asset Ownership & 0.25 & 0.43 \\
Plans on Returning Home & 0.07 & 0.26 \\
Plans on Bringing the Family & 0.24 & 0.43 \\
Remits to Parents & 0.22 & 0.41 \\
Remits to Partner & 0.03 & 0.17 \\
Remits to Children & 0.09 & 0.28 \\
Remits to Siblings & 0.07 & 0.26 \\
Remits to Other Family & 0.04 & 0.20 \\
Remits to Other Individuals & 0.01 & 0.10 \\
Africa & 0.11 & 0.31 \\
America & 0.34 & 0.47 \\
EU Members & 0.48 & 0.50 \\
Europe Non-EU Members & 0.07 & 0.25 \\
GDP Growth Rate & 4.34 & 2.68 \\
Real Interest Rate & 0.18 & 3.04 \\
Real Exchange Rate Depreciation & 0.01 & 0.17 \\
Real Exchange Rate Volatility & 0.02 & 0.01 \\
\hline \hline
\end{tabular}




\section{DATA APPENDIX}

\section{Derivation and data sources for the macroeconomic variables used in the analysis}

1. Real interest rates: Deposit interest rates come from International Financial statistics (variable 60L..zf). If the deposit rate is not reported by IFS Statistics, a similar interest rate variable is used in its place. Inflation rates are subtracted from the nominal interest rate to obtain real interest rates. Inflation rates are constructed from the CPI index (line 64..zf), when available, or from a close substitute when unavailable.

2. Real GDP growth: Measured by real per capita GDP growth rates for 2006 for the individual countries come from World Development Indicators online.

3. Real exchange rate movements: Real exchange rates are constructed from nominal exchange rates and price indexes extracted from IFS statistics. The nominal exchange rate is from line WA.ZF or AA.ZF the CPI from line 64..zf. The real exchange rate is constructed for each month in 2006 as:

$$
\text { Real Exchange } \text { Rate }_{t}=\frac{e_{\text {home currency/euro }} \times P_{\text {Spain }}}{P_{\text {home country }}}
$$

where $e$ represents the nominal exchange rate and $P$ the CPI index. The home currency depreciation rate is defined for each month as follows:

$$
\text { Real exchange rate depreciation } \mathrm{t}_{\mathrm{t}}=\log \left(\text { real }_{t}\right)-\log \left(\text { real }_{t-1}\right)
$$

Monthly real exchange depreciation rates are averaged for any given year to derive the yearly average real exchange depreciation rate.

4. Real exchange rate volatility: Measured using the standard deviation of the monthly log differenced real exchange rates is computed to derive a measure of yearly real exchange rate volatility. 